\title{
RESPONS MASYARAKAT TERHADAP EKSISTENSI SASTRA LISAN PALEBOHU: STUDI PENDAHULUAN BERDASARKAN TEORI RESEPSI RIEN T. SEGERS
}

\author{
Herman Didipu, Windy Putri Mustafa, Nurfaizah Abdullah \\ Fakultas Sastra dan Budaya \\ Universitas Negeri Gorontalo \\ herdi.ung@gmail.com \\ nurfaizahabdullah09@gmail.com
}

\begin{abstract}
Abstrak
Penelitian ini memfokuskan kajian pada respons masyarakat terhadap eksistensi sastra lisan palebohu, yaitu mencakup: (a) kebermaknaan puisi lisan palebohu, (b) relevansi puisi lisan palebohu dengan perkembangan zaman, (c) manfaat puisi lisan palebohu untuk pengantin dan pendengar, serta (d) pelestarian puisi lisan palebohu. Teori yang digunakan adalah teori resepsi eksperimental Rien T. Segers. Data dikumpulkan dengan cara membagikan angket yang berisi pertanyaan-pertanyaan kepada para responden. Adapun responden penelitian ini adalah masyarakat di desa Huntulohulawa, Kecamatan Bongomeme, Kabupaten Gorontalo, yang berjumlah 25 orang. Analisis data dilakukan secara kuantitatif dan kualitatif. Data kuantitatif dianalisis dengan menggunakan rumus, dan data kualitatif dianalisis dengan cara mendeskripsikan dan menginterpretasi hasil angket yang diisi oleh responden. Berdasarkan uraian pada pembahasan, dapat ditarik simpulan sebagai berikut. Pertama, secara fisik dalam penampilan, sastra lisan palebohu sudah jarang bahkan tidak ada lagi dalam upacara adat perkawinan masyarakat Gorontalo saat ini. Kedua, meskipun tidak dapat ditemukan lagi dalam upacara adat perkawinan, masyarakat masih menanggapi positif eksistensi sastra lisan palebohu karena dianggap masih bermakna, masih relevansi dengan perkembangan zaman sekarang, dianggap bermanfaat bagi untuk pendengar (khususnya pengantin), serta masih adanya adanya kesempatan untuk melestarikan puisi lisan palebohu.

Kata kunci: respons masyarakat, eksistensi, palebohu
\end{abstract}

Asbtract

This study focuses the study on public response to the existence of palebohu oral literature, which includes: (a) the significance of palebohu oral poetry, (b) the relevance of palebohu oral poetry with the times, (c) the benefits of palebohu oral poetry for brides and listeners, and (d) ) preservation of Palebohu's oral poetry. The theory used is the experimental reception theory of Rien T. Segers. Data was collected by distributing questionnaires containing questions to the respondents. The respondents of this study were 25 people in the village of Huntulohulawa, Bongomeme District, Gorontalo Regency. Data analysis was carried out quantitatively and qualitatively. Quantitative data were analyzed using formulas, and qualitative data were analyzed by describing and interpreting the results of questionnaires filled out by respondents. Based on the description in the discussion, the following conclusions can be drawn. First, physically in appearance, Palebohu's oral literature is rarely even no longer present in Gorontalo traditional wedding ceremonies today. Second, although it cannot be found anymore in traditional marriage ceremonies, people still respond positively to the existence of palebohu oral literature because it is considered still 
meaningful, still relevant to current developments, considered beneficial for listeners (especially brides), and there are still opportunities to preserve poetry oral palebohu. Keywords: community response, existence, palebohu

\section{PENDAHULUAN}

Pelebohu merupakan salah satu ragam sastra lisan Gorontalo. Sastra lisan palebohu digunakan pada dua upacara adat masyarakat Gorontalo, yaitu penobatan (momulanga) dan perkawinan (moponika). Jika dibandingkan dengan ragam sastra lisan Gorontalo lainnya, palebohu merupakan salah satu ragam sastra lisan yang sudah sangat jarang ditemukan dalam keseharian masyarakat Gorontalo. Hal ini dapat dilihat pada realitas berikut ini. Upacara adat penobatan di dalamnya masih ada pembacaan palebohu, namun karena upacara ada ini hanya dilaksanakan sesekali jika ada pejabat yang dinobatkan, maka sangat jarang ditemui. Palebohu juga dilantunkan pada upacara adat perkawinan, namun realitas di lapangan, sudah tidak ada lagi tahapan pembacaan palebohu oleh tokoh adat seperti yang dilaksanakan pada zaman dahulu. Akibatnya, generasi sekarang ini tidak memahami lagi, bahkan tidak kenal lagi dengan sastra lisan palebohu. Realitas ini berimplikasi pada eksistensi sastra palebohu sebagai salah satu khazanah kebudayaan Gorontalo, dan eksistensi alebohu sebagai panduan dan pedoman bagi masyarakat Gorontalo dalam menjalankan kehidupan.

Khusus pada upacara adat perkawinan, palebohu berisi nasihat-nasihat yang sangat penting bagi kedua mempelai yang akan mengarungi bahtera kehidupan berumah tangga. Di dalamnya disajikan arahan, panduan, bahkan pedoman positif untuk mewujudkna keluarga sakinah, mawaddah, dan warahmah. Palebohu menyuguhkan solusi-solusi dalam menghadapi tantangan dalam berumah tangga. Seperti diketahui bersama, kehidupan berumah tangga seperti orang yang sedang berlayar. Pasti dipenuhi badai dan rintangan. Jika gagal menghadapi badai dan rintangan, maka kapal akan tenggelam. Sebaliknya, jika mampu menghadapinya dengan sabar dan ikhlas, niscaya kapal akan kokoh dan bertahan lama. Rumah tangga yang tidak mampu menghadapi masalah, pasti akan berakhir dengan perceraian. Sebaliknya, rumah tangga yang sabar dan ikhlas dalam menjalani segala ujian dan cobaan, akan langgeng dan kokoh hingga maut memisahkan keduanya.

Palebohu mengilustrasikan berbagai cobaan dalam berumat tangga, dan memaparkan solusi untuk menghadapinya. Ada yang disampaikan dengan bahasa yang lugas, namun ada pula yang disampaikan secara tersirat melalui bahasa-bahasa simbolik. Nasihat yang terkandung di dalamnya tidak hanya bermanfaat bagi pengantin baru, namun juga bermanfaat bagi keluarga yang telah lama dibangun. Ilustrasi dan solusi berumah tangga di dalamnya dapat dijadikan pedoman dalam menjalankan bahtera rumah tangga, baik bagi keluarga baru maupun yang sudah lama.

Kenyataanya palebohu ini sudah tidak lagi digunakan oleh masyarakat Gorontalo. Hal ini disebabkan karena faktor semakin kurangnya penutur asli dari puisi lisan palebohu tersebut dan semakin berkembangnya zaman moderen. Beberapa faktor umum lainnya juga yang menyebabkan terhambatnya perkembangan dan pengembangan puisi lisan palebohu yaitu generasi muda kurang memiliki minat dan 
cenderung kurang menguasai bahasa daerahnya sendiri (bahasa Gorontalo) secara baik dan benar. Tidak hanya generasi muda saja, sebagian orang tua yang sudah lama tinggal di kota/perantauan, cenderung tidak menguasai atau menggunakan lagi ciri khas dari daerah Gorontalo dalam kegiatan/upacara adat.

Berangkat dari hal-hal tersebut, penting untuk dilakukan penelitian yang berkaitan dengan respons masyarakat tentang eksistensi sastra lisan palebohu. Dengan memanfaatkan teori resepsi Rien T. Segers, penelitian ini difokuskan pada respons masyarakat terhadap: (a) kebermaknaan puisi lisan palebohu, (b) relevansi puisi lisan palebohu dengan perkembangan zaman, (c) manfaat puisi lisan palebohu untuk pengantin dan pendengar, serta (d) pelestarian puisi lisan palebohu.

\section{METODE}

Metode yang digunakan dalam penelitian ini adalah metode resepsi eksperimental yang dikemukakan oleh Segers. Data dikumpulkan dengan cara membagikan angket yang berisi pertanyaan-pertanyaan kepada para responden. Adapun responden penelitian ini adalah masyarakat di desa Huntulohulawa, Kecamatan Bongomeme, Kabupaten Gorontalo, yang berjumlah 25 orang. Analisis data dilakukan secara kuantitatif dan kualitatif. Data kuantitatif dianalisis dengan menggunakan rumus, dan data kualitatif dianalisis dengan cara mendeskripsikan dan menginterpretasi hasil angket yang diisi oleh responden. Adapun rumus yang digunakan sebagai berikut.

$$
\begin{aligned}
p=\frac{f}{N} \times 100 \% \quad \text { Keterangan : } & \mathrm{p} \\
\mathrm{f} & =\text { Angka Persentase } \\
\mathrm{N} & =\text { Jumlahs subjek atau responden }
\end{aligned}
$$

\section{HASIL DAN PEMBAHASAN}

\section{Kebermaknaan Puisi Lisan Palebohu}

Untuk melihat eksistensi puisi lisan palebohu dari segi kebermaknaan di desa Huntulohulawa Kecamatan Bongomeme, responden diberikan beberapa pertanyaan: apakah puisi lisan palebohu menarik untuk didengar?, apakah bapak/ibu/saudara mengerti dengan puisi lisan palebohu yang disampaikan? apakah pelaksanaan puisi lisan palebohu memiliki tujuan?. Hasil tersebut dapat dilihat pada tabel dibawah ini.

Tabel 1. Ketertarikan terhadap Palebohu

\begin{tabular}{ccccc}
\hline \multirow{2}{*}{ Indikator } & \multicolumn{2}{c}{ Jawaban Respoden } & \multicolumn{2}{c}{ Presentase } \\
\cline { 2 - 5 } & Ya & Tidak & Ya & Tidak \\
\hline $\begin{array}{l}\text { Menurut Bapak/Ibu/Saudara } \\
\text { apakah puisi lisan palebohu }\end{array}$ & 25 & 0 & $100 \%$ & 0 \\
ini menarik untuk di dengar? & & & & \\
\hline
\end{tabular}

Tabel 1 di atas menunjukkan bahwa 100\% responden menjawab ya atau memberikan respon bahwa puisi lisan palebohu bagus untuk didengar karena puisi lisan palebohu merupakan adat Gorontalo yang mengandung nasihat untuk pernikahan, dan sajaknya tersusun rapi dan menarik. Pertanyaan di atas termasuk dalam aspek intelektual karena berkaitan dengan pengetahuan masyarakat tentang 
puisi lisan palebohu menarik atau tidak. Berikut respon masyarakat desa Huntulohulawa Kecamatan Bongomeme dapat dilihat sebagai berikut.

Alasan pertama masyarakat desa Huntulohulawa Kecamatan Bongomeme yang menanggapi bahwa puisi lisan palebohu bagus didengar karena puisi lisan palebohu merupakan salah satu puisi lisan yang digunakan dalam adat yang ada di Gorontalo yang memiliki sajak yang rapi dan menarik. Masyarakat menanggapi demikian, karena mereka sudah mendengar dan dan membaca puisi lisan palebohu secara langsung sehingga mereka menanggapi bahwa puisi lisan palebohu memiliki sajak yang rapi dan menarik. Selain itu, puisi lisan palebohu merupakan puisi adat yang digunakan dalam pesta pernikahan yang menggunakan bahasa Gorontalo asli yang mungkin sudah jarang didengar oleh masyarakat.

Alasan kedua, karena puisi lisan palebohu mengandung nasihat atau pengajaran yang baik untuk pengantin baru yang telah melangsungkan pernikahan. Nasihat yang ada dalam puisi lisan palebohu bertujuan untuk membuat pengantin dapat mengarungi bahtera rumah tangga dengan sakinah, mawwadah, dan warahmah.

Alasan ketiga, karena sajak yang ada dalam puisi lisan palebohu tersusun rapi dan menarik. Selain itu, puisi lisan palebohu juga memiliki cara pengucapan atau intonasi yang indah yang membuat puisi lisan palebohu ini semakin bagus untuk didengar. Ketiga respons atau alasan dari masyarakat di atas termasuk dalam aspek intelektual atau aspek pengetahuan.

Berikut di bawah ini tabel untuk melihat eksistensi puisi lisan palebohu ditinjau dari pemahaman masyarakat terhadap palebohu yang disampaikan.

Tabel 2. Pemahaman terhadap Palebohu

\begin{tabular}{lcccc}
\hline \multirow{2}{*}{ Indikator } & \multicolumn{2}{c}{ Jawaban Respoden } & \multicolumn{2}{c}{ Presentase } \\
\cline { 2 - 5 } & Ya & Tidak & Ya & Tidak \\
\hline $\begin{array}{l}\text { Apakah Bapak/Ibu/Saudara } \\
\text { mengerti dengan puisi lisan } \\
\begin{array}{l}\text { palebohu yang } \\
\text { disampaikan? }\end{array}\end{array}$ & 22 & 3 & $88 \%$ & $12 \%$ \\
\hline
\end{tabular}

Tabel 2 menunjukkan bahwa 88\% responden menjawab ya dan 12\% lainnya menjawab tidak. Responden yang menjawab ya mengatakan bahwa mereka mengerti puisi lisan palebohu yang disampaikan, dengan respons bahwa mereka mengerti dengan bahasa Gorontalo karena itu merupakan bahasa yang sering mereka gunakan dalam berkomunikasi. Pertanyaan tersebut termasuk ke dalam aspek intelektual atau aspek pengetahuan, karena membutuhkan pengetahuan masyarakat dalam menjawab apakah mereka mengerti atau tidak dengan puisi lisan palebohu yang disampaikan. Berikut respons yang disampaikan.

Alasan pertama masyarakat desa Huntulohulawa Kecamatan Bongomeme menanggapi bahwa mereka mengerti puisi lisan palebohu karena penyampaian puisi lisan palebohu menggunakan bahasa Gorontalo yang sering mereka gunakan dalam berkomunikasi. Bahasa Gorontalo merupakan salah satu bagian dari 671 bahasa daerah yang ada di Indonesia. Jadi, jika masyarakat itu benar-benar asli masyarakat Gorontalo maka tidak mungkin mereka tidak mengerti dengan bahasa yang digunakan dalam menyampaikan puisi lisan palebohu. Sebab, puisi lisan palebohu merupakan salah satu 
adat yang ada di daerah Gorontalo maka tidak heran jika bahasa yang digunakan adalah bahasa Gorontalo yang isinya menarik untuk didengar. Respons tersebut termasuk dalam aspek intelektual sebab, masyarakat memiliki pengetahuan tentang bahasa Gorontalo sehingga mereka mengerti dengan puisi lisan palebohu yang disampaikan.

Responden yang menjawab tidak mengerti dengan bahasa yang digunakan dalam penyampaian puisi lisan palebohu disebabkan oleh mereka bukan penduduk asli daerah Gorontalo (desa Huntulohulawa). Mereka hanyalah penduduk pindahan yang sudah berdomisili di desa Huntulohulawa Kecamatan Bongomeme.

Berikut di bawah ini tabel untuk melihat eksistensi puisi lisan palebohu dari segi kebermaknaan dengan pertanyaan apakah pelaksanaan puisi lisan palebohu memiliki tujuan?

Tabel 3. Pentingnya Palebohu

\begin{tabular}{lcccc}
\hline \multirow{2}{*}{ Indikator } & \multicolumn{2}{c}{ Jawaban Respoden } & \multicolumn{2}{c}{ Presentase } \\
\cline { 2 - 5 } & Ya & Tidak & Ya & Tidak \\
\hline $\begin{array}{l}\text { Menurut Bapak/Ibu/Saudara } \\
\text { apakah pelaksanaan puisi }\end{array}$ & 21 & 4 & & \\
$\begin{array}{l}\text { lisan palebohu memiliki } \\
\text { tujuan? }\end{array}$ & & & $84 \%$ & $16 \%$ \\
\hline
\end{tabular}

Tabel 3 menunjukkan bahwa 84\% responden yang menjawab ya dan $16 \%$ responden yang menjawab tidak. Responden yang menjawab ya memiliki respons bahwa tujuan dari puisi lisan palebohu ini adalah untuk memberikan nasihat atau membimbing kedua pengantin sehingga dapat mencapai kebahagiaan dalam berumah tangga. Selain itu, pelaksanaan puisi lisan palebohu yaitu untuk pelestarian budaya Gorontalo. Pertanyaan di atas termasuk pada aspek intelektual sebab, membutuhkan wawasan atau pengetahuan dari masyarakat terhadap tujun yang ada di setiap pelaksanaan palebohu. Berikut kedua alasan dari respons masyarakat desa Huntulohulawa kecamatan Bongomeme dapat diuraikan di bawah ini.

Tujuan pertama dari pelaksanaan puisi lisan palebohu menurut respons masyarakat desa Huntulohulawa Kecamatan Bongomeme yaitu bertujuan untuk memberikan nasihat atau membimbing kedua pengantin sehingga dapat mencapai kebahagiaan dalam berumah tangga. Dalam setiap berumah tangga pasti akan ada beberapa masalah atau kendala yang akan dihadapi baik dari perbedaan pendapat, sikap dan lainnya yang semuanya itu akan berpengaruh pada kebahagiaan dalam rumah tangga. Jika tidak diantisipasi terlebih dahulu, maka pernikahan tersebut akan hancur berantakan. Oleh karena itu, tujuan dari puisi lisan palebohu adalah untuk mencegah hal-hal buruk yang akan terjadi dalam sebuah pernikahan. Hal ini tersebut berkaitan dengan penanaman nilai moral, agama, sosial budaya, etika dan nilai kekeluargaan yang semuanya sangat penting bagi pengantin dalam mengarungi bahtera rumah tangga.

Tujuan kedua dari pelaksanaan puisi lisan palebohu menurut respons masyarakat desa Huntulohulawa Kecamatan Bongomeme yaitu sebagai salah satu pelestarian budaya atau adat yang ada di daerah Gorontalo. Puisi lisan palebohu merupakan salah satu adat dan kebudayaan daerah Gorontalo yang sudah tidak lagi 
dikenal oleh banyak orang. Adanya pelaksaan puisi lisan palebohu dalam setiap acara pernikahan ini diharapkan bisa membuka pengetahuan dan wawasan masyarakat terhadap puisi lisan palebohu. Kedua respons tersebut termasuk dalam aspek intelektual atau pengetahuan Masyarakat desa Huntulohulawa Kecmatan Bongomeme

\section{Relevansi Puisi Lisan Palebohu dengan Perkembangan Zaman}

Untuk melihat eksistensi puisi lisan palebohu dari aspek relevansi puisi lisan palebohu dengan perkembangan zaman sekarang. Maka dapat dilihat melalui empat pertanyaan. Pertama, Apakah di Desa Huntulohulawa Kecamatan Bongomeme masih dilaksanakan puisi lisan palebohu dalam adat pernikahan? Kedua, yaitu apakah isi puisi lisan palebohu sesuai dengan keadaan zaman yang terus berkembang?, Ketiga, yaitu apakah generasi muda memiliki sikap simpati terhadap puisi lisan palebohu? dan Keempat, apakah puisi lisan palebohu memiliki pengaruh pada pengantin baru jika tidak dilaksanakan dalam adat pernikahan?. Hasil tersebut dapat dilihat dari tabel di bawah ini.

Tabel 4. Pelaksanaan Palebohu

\begin{tabular}{lcccc}
\hline \multirow{2}{*}{ Indikator } & \multicolumn{2}{c}{ Jawaban Respoden } & \multicolumn{2}{c}{ Presentase } \\
\cline { 2 - 5 } & Ya & Tidak & Ya & Tidak \\
\hline $\begin{array}{l}\text { Apakah di Desa } \\
\text { Huntulohulawa Kecamatan }\end{array}$ & & & & \\
$\begin{array}{l}\text { Bongomeme masih } \\
\text { dilaksanakan puisi lisan } \\
\text { palebohu dalam adat } \\
\text { pernikahan? }\end{array}$ & 19 & 6 & $76 \%$ & $24 \%$ \\
\hline
\end{tabular}

Tabel 4 menunjukkan bahwa $76 \%$ responden menjawab ya dan $24 \%$ responden yang menjawab tidak. Responden yang menjawab ya memiliki respons bahwa puisi lisan palebohu ini masih dilaksanakan karena puisi lisan palebohu merupakan adat dan tradisi yang ada di Gorontalo, dan responden lainnya juga menanggapi bahwa puisi lisan palebohu masih dilaksanakan dalam adat pernikahan tetapi sudah jarang atau hanya dilaksanakan dalam waktu-waktu tertentu, yaitu pada adat yang pohu-pohutu. Responden sebanyak 24\% menjawab tidak karena mereka belum pernah melihat pernikahan yang ada palebohu. Pertanyaan di atas termasuk pada aspek intelektual sebab masyarakat menguraikan atau mengutarakan pengetahuan yg mereka ketahui kepada peneliti. Berikut ketiga alasan dari respons masyarakat desa Huntulohulawa Kecamatan Bongomeme dapat dilihat dari uraian di bawah ini.

Pertama, masyarakat desa Huntulohulawa Kecamatan Bongomeme yang menanggapi bahwa puisi lisan palebohu masih dilaksanakan dalam adat pernikahan karena puisi lisan palebohu merupakan adat dan tradisi yang ada di daerah Gorontalo yang masih perlu dilestarikan dan diperkenalkan kepada seluruh masyarakat Gorontalo atau kepada generasi yang akan datang. Puisi lisan palebohu merupakan salah satu adat dan tradisi daerah Gorontalo yang selalu dilaksanakan dalam pesta pernikahan melalui kerja sama antara pemerintah, tokoh agama, dan tokoh adat.

Kedua, masyarakat desa Huntulohulawa Kecamatan Bongomeme yang menanggapi bahwa puisi lisan palebohu masih dilaksanakan dalam pesta pernikahan tetapi sudah jarang atau hanya dilaksanakan dalam waktu-waktu tertentu yaitu pada 
adat yang lengkap atau dalam istilah bahasa Gorontalo adat pohu-pohutu. Adat pohupohutu merupakan salah satu adat yang lengkap.

Ketiga, masyarakat desa Huntulohulawa Kecamatan Bongomeme yang menjawab "tidak" memberikan respons bahwa mereka belum pernah melihat pernikahan yang ada palebohu, karena puisi lisan palebohu ini hanya digunakan pada adat yang lengkap. Jadi tidak semua masyarakat yang dapat menggunakan puisi lisan palebohu ini dalam pernikahan. Oleh sebab itu, puisi lisan palebohu ini jarang dilihat atau diketahui oleh masyarakat. Ketiga respons di atas termasuk dalam kategori respons intelektual karena jawaban dari pertanyaan di atas membutuhkan pengetahuan atau wawasan dari respons masyarakat Desa Huntulohulawa Kecamatan Bongomemes

Berikut di bawah ini tabel untuk melihat eksistensi puisi lisan palebohu dari segi relevansi dengan keadaan zaman yang terletak pada pertanyaan kedua yaitu apakah isi puisi lisan palebohu sesuai dengan keadaan zaman yang terus berkembang?.

Tabel 5. Relevansi Puisi Lisan Palebohu

\begin{tabular}{lcccc}
\hline \multirow{2}{*}{ Indikator } & \multicolumn{2}{c}{ Jawaban Respoden } & \multicolumn{2}{c}{ Presentase } \\
\cline { 2 - 5 } & Ya & Tidak & Ya & Tidak \\
\hline $\begin{array}{l}\text { Menurut Bapak/Ibu/Saudara } \\
\text { apakah isi puisi lisan }\end{array}$ & & & & \\
$\begin{array}{l}\text { palebohu sesuai dengan } \\
\text { keadaan zaman yang terus } \\
\text { berkembang? }\end{array}$ & 16 & 9 & $64 \%$ & $36 \%$ \\
\hline
\end{tabular}

Tabel 5 menunjukkan bahwa 64\% yang menjawab ya dan $36 \%$ responden yang menjawab tidak. Responden yang menjawab ya memiliki respons bahwa puisi lisan palebohu bersifat fleksibel dan umum. Respons berikutnya yang mengatakan bahwa puisi lisan palebohu masih sesuai dengan keadaan zaman karena masih dilestarikan di desa Huntulohulawa Kecamatan Bongomeme. Responden yang menjawab tidak, memiliki respons bahwa puisi lisan palebohu sudah tidak sesuai lagi dengan perkembangan zaman karena tetap menggunakan bahasa Gorontalo asli sedangkan sekarang sudah zaman moderen. Pertanyaan di atas termasuk pada aspek intelektual atau pengetahuan sebab,membutuhkan pengetahuan lebih dalam dan lebih luas dari respons. Berikut ketiga respons dari responden di atas yaitu:

Respons pertama dari responden yang mengatakan bahwa puisi lisan palebohu masih sesuai dengan keadaan zaman yaitu, karena puisi lisan palebohu bersifat fleksibel atau bersifat umum. Puisi lisan palebohu bisa mengikuti arus perubahan zaman karena isinya selalu membicarakan tentang kehidupan-kehidupan yang ada dalam pernikahan seperti petunjuk atau pengajaran tentang cara orang bertingkah laku dalam kehidupan berumah tangga ataupun kehidupan bermasyarakat sehari-hari.

Respons kedua dari responden yaitu karena masih dilestarikan atau dikembangkan di desa Huntulohulawa Kecamatan Bongomeme. Bentuk pelestarian atau pengembangan puisi lisan palebohu di desa Huntulohulawa Kecamatan Bongomeme yaitu dengan adanya pengajaran puisi lisan palebohu kepada anak-anak. Anak-anak merupakan salah satu penerus yang akan selalu membawa adat atau pengetahuan yang mereka miliki atau pelajaran yang mereka pelajari sebelumnya. Jadi, dengan cara ini puisi lisan palebohu dengan sendirinya akan sesuai dengan 
keadaan zaman yang terus berkembang pesat karena ada yang menunjang atau yang mempelajari puisi lisan palebohu tersebut.

Respons ketiga dari responden yang menjawab bahwa puisi lisan palebohu sudah tidak sesuai dengan perkembangan zaman sekarang, karena puisi lisan palebohu tetap menggunakan bahasa Gorontalo asli sedangkan sekarang sudah zaman moderen. Akan tetapi, jika dilihat dari keberadaannya puisi lisan palebohu merupakan salah satu adat dan kebudayaan Gorontalo. Jadi, tidak dipungkiri lagi bahasa yang digunakan dalam penyampaian puisi lisan palebohu menggunakan bahasa Gorontalo. Puisi lisan palebohu ini juga tidak hanya menggunakan bahasa Gorontalo, tetapi juga menggunakan bahasa Indonesia yaitu bahasa yang sering digunakan oleh masyarakat dalam setiap berkomunikasi sehari-hari. Puisi lisan palebohu juga tidak selalu menggunakan bahasa Gorontalo adapula yang menggunakan bahasa Indonesia. Contohnya nasihat-nasihat yang diberikan oleh Kantor Urusan Agama kepada kedua mempelai yang akan memasuki rumah tangga baru. Jadi, puisi lisan palebohu akan tetap sesuai dengan perkembangan zaman.

Berikut di bawah ini tabel untuk melihat eksistensi puisi lisan palebohu dari segi relevansi dengan keadaan zaman yang terletak pada pertanyaan ketiga yaitu apakah generasi muda memiliki sikap simpati terhadap puisi lisan palebohu?

Tabel 6. Tanggapan Generasi Muda

\begin{tabular}{lcccc}
\hline \multirow{2}{*}{ Indikator } & \multicolumn{2}{c}{ Jawaban Respoden } & \multicolumn{2}{c}{ Presentase } \\
\cline { 2 - 5 } & Ya & Tidak & Ya & Tidak \\
\hline $\begin{array}{l}\text { Apakah generasi muda } \\
\text { memiliki sikap simpati }\end{array}$ & $17 \%$ & $8 \%$ & $68 \%$ & $32 \%$ \\
$\begin{array}{l}\text { terhadap puisi lisan } \\
\text { palebohu? }\end{array}$ & & & & \\
\hline
\end{tabular}

Tabel di atas merupakan pertanyaan untuk aspek intelektual atau pengetahuan sebab, membutuhkan pengetahuan lebih dalam atau luas tentang apakah generasi muda memiliki simpati terhadap puisi lisan palebohu. Hasil tersebut menunjukkan bahwa $68 \%$ responden menjawab ya dan $32 \%$ lainnya menjawab tidak. Responden yang berjumlah $68 \%$ berpendapat bahwa generasi muda masih memiliki sikap simpati terhadap puisi lisan palebohu yaitu sebagai berikut.

Pertama, karena kehidupan sosial masyarakat dikalangan generasi muda masih beretika berdasarkan adat dan kebudayaan. Etika merupakan suatu penggambaran sikap yang baik dan yang buruk. Jika, dikatakan bahwa masyarakat masih beretika, berarti masyarakat masih memiliki sikap yang baik terhadap keberadaan puisi lisan palebohu yang akan membuat generasi muda ini memiliki sikap simpati untuk selalu mempelajari puisi lisan palebohu tersebut.

Kedua, hal yang membuat generasi muda masih memiliki sikap simpati terhadap puisi lisan palebohu karena cara penyampaian atau pelaksanaan puisi lisan palebohu yang menarik atau berbeda dan yang paling utamanya adalah karena puisi lisan palebohu membahas tentang nasihat pernikahan. Generasi muda yang nantinya akan menuju jenjang pernikahan dengan sendirinya mereka akan merasa tertarik atau simpati terhadap puisi lisan palebohu tersebut karena isi yang ada di dalamnya sangat penting untuk dipelajari, menimbulkan rasa ingin tahu, dan rasa penasaran mereka. 
Jika kedua rasa itu timbul maka mereka akan memiliki sikap simpati dan tidak akan segan-segan mau mempelajari puisi lisan palebohu dengan cara mendengar dan memahami setiap isi yang ada dalam puisi lisan palebohu.

Responden yang menjawab bahwa $32 \%$ mengemukakan generasi muda sudah tidak lagi memiliki sikap simpati terhadap puisi lisan palebohu sebab mereka tidak mengerti. Perkembangan puisi lisan palebohu sekarang ini sudah mulai mengalami pengikisan. Pada hal jika dipikir, sikap generasi muda yang tidak tahu dan tidak ingin cari tahu itulah yang membuat generasi muda tidak memiliki rasa simpati lagi terhadap puisi lisan palebohu.

Berikut di bawah ini tabel untuk melihat eksistensi puisi lisan palebohu dari segi relevansi dengan keadaan zaman yang terletak pada pertanyaan terakhir yaitu apakah puisi lisan palebohu ini memiliki pengaruh kepada pengantin jika tidak dilaksanakan dalam adat pernikahan?

Tabel 7. Pengaruh Tembang Palebohu

\begin{tabular}{lcccc}
\hline \multirow{2}{*}{ Indikator } & \multicolumn{2}{c}{ Jawaban Respoden } & \multicolumn{2}{c}{ Presentase } \\
\cline { 2 - 5 } & Ya & Tidak & Ya & Tidak \\
\hline $\begin{array}{l}\text { Menurut } \\
\text { Bapak/Ibu/Saudara apakah }\end{array}$ & & & & \\
$\begin{array}{l}\text { puisi lisan palebohu ini } \\
\text { memiliki pengaruh kepada } \\
\text { pengantin baru jika tidak } \\
\text { dilaksanakan dalam adat } \\
\text { pernikahan? }\end{array}$ & 13 & 12 & $52 \%$ & $48 \%$ \\
\hline
\end{tabular}

Tabel 7 merupakan pertanyaan untuk kategori aspek intelektual atau pengetahuan sebab membutuhkan wawasan dari masyarakat apakah berpengaruh atau tidak puisi lisan palebohu dalam pelakasanaan adat pernikahan. Hasil tersebut menunjukkan bahwa puisi lisan palebohu berpengaruh jika tidak dilaksanakan dalam adat pernikahan perbedaannya hanya berkisar antara $52 \%$ dan $48 \% .52 \%$ responden yang menjawab ya dan $48 \%$ yang menjawab tidak berpengaruh Berikut respons dari masyarakat desa Huntulohulawa Kecamatan Bongomeme.

Pertama, puisi lisan palebohu mengandung nasihat yang baik untuk pernikahan, karena dapat membuat rumah tangga mereka menjadi rumah tangga yang harmonis. Menjalani hubungan rumah tangga tidak semudah yang kita bayangkan. Dalam kehidupan rumah tangga pasti akan dihadapi pahit dan manisnya kehidupan, sehingga dengan dilaksanakannya puisi lisan palebohu dalam adat pernikahan adalah untuk mencegah munculnya masalah tersebut. Mereka yang sudah diberikan nasihat melalui palebohu saja belum tentu mengamalkan dan bisa membuat hubungan pernikahan mereka tetap harmoni apalagi jika tidak diberikan nasehat, mungkin saja dalam pernikahan mereka akan selalu mengalami pertengkaran dan hal yang paling terburuk yaitu perpisahan atau perceraian.

Kedua, responden berpendapat bahwa pelaksanaan puisi lisan palebohu dalam adat pernikahan tidak akan berpengaruh kepada pengantin, karena semua itu tergantung pada orang (pengantin) yang akan melaksanakan atau menjalani ikatan pernikahan tersebut. Sebelum mengambil keputusan untuk menikah kedua pengantin sudah berpikir bahwa dalam hubungan pernikahan tidak akan selalu bahagia, pasti 
akan ada pertengkaran tetapi tinggal bagaimana sikap pengantin untuk selalu sabar mengadapi semua cobaan dalam hubungan pernikahan.

\section{Manfaat Puisi Lisan Palebohu untuk Pendengar (Pengantin)}

Untuk melihat eksistensi puisi lisan palebohu maka dapat dilihat dari segi kemanfaatan yang dapat diketahui dari dua aspek yaitu aspek intelektual dan aspek emosional. Hasil ini dapat dilihat dari respons masyarakat desa Huntulohulawa Kecamatan Bongomeme yang dapat dilihat pada tabel di bawah ini.

\begin{tabular}{lcccc}
\multicolumn{4}{c}{ Tabel 8. Manfaat Puisi Lisan Palebohu } \\
\hline \multirow{2}{*}{ Indikator } & \multicolumn{2}{c}{ Jawaban Respoden } & \multicolumn{2}{c}{ Presentase } \\
\cline { 2 - 5 } & Ya & Tidak & Ya & Tidak \\
\hline $\begin{array}{l}\text { Menurut } \\
\begin{array}{l}\text { Bapak/Ibu/Saudara apakah } \\
\text { puisi lisan palebohu }\end{array}\end{array}$ & 23 & 2 & & \\
$\begin{array}{l}\text { memiliki manfaat bagi } \\
\text { pengantin baru }\end{array}$ & & & & \\
\hline
\end{tabular}

Tabel 8 menunjukkan bahwa puisi lisan palebohu memiliki manfaat bagi pengantin baru. Hal ini dapat dilihat dari $92 \%$ responden menjawab ya dan $8 \%$ responden yang menjawab tidak. Pertanyaan tersebut ke dalam aspek intelektual karena memerlukan wawasan dari responden. Reponden yang menjawab ya memiliki alasan dapat membantu mengarahkan pengantin baru dalam menjalani kehidupan rumah tangga yang sakinah, mawwadah, warahmah. Puisi lisan palebohu memiliki manfaat yang baik bagi pengantin karena dalam puisi lisan palebohu tersebut terdapat nasehat yang baik untuk pengantin. Akan tetapi, hal ini dikembalikan lagi kepada orang yang diberikan nasihat, apakah bisa melaksanakan setiap nasihat yang tergandung dalam isi puisi lisan palebohu atau tidak.

Alasan masyarakat yang menanggapi bahwa puisi lisan palebohu tidak memiliki manfaat bagi pengantin baru, karena menurut mereka puisi lisan ini hanyalah adat. Jadi, tidak akan memiliki manfaat kepada pengantin baru. Pendapat yang demikian itulah yang salah, karena setiap adat yang ada di daerah Gorontalo pastilah memiliki atau mengandung makna kehidupan.

\section{Pelestarian Puisi Lisan Palebohu}

Untuk melihat eksistensi puisi lisan palebohu maka dapat dilihat dari segi pelestarian puisi lisan palebohu. Berikut di bawah ini tabel untuk melihat eksistensi puisi lisan palebohu dilihat dari segi pelestarian puisinya.

Tabel 9. Penarapan Isi Puisi Lisan Palebohu

\begin{tabular}{lcccc}
\hline \multirow{2}{*}{ Indikator } & \multicolumn{2}{c}{ Jawaban Respoden } & \multicolumn{2}{c}{ Presentase } \\
\cline { 2 - 5 } & Ya & Tidak & Ya & Tidak \\
\hline $\begin{array}{l}\text { Menurut } \\
\begin{array}{l}\text { Bapak/Ibu/Saudara apakah } \\
\text { disetiap keluarga sekarang }\end{array}\end{array}$ & & & & \\
$\begin{array}{l}\text { masih menerapkan nasihat } \\
\text { palebohu dalam kehidupan }\end{array}$ & 15 & 10 & $60 \%$ & $40 \%$ \\
Sehari-hari? & & & & \\
\hline
\end{tabular}


Tabel 9 menunjukkan bahwa disetiap keluarga sekarang masih menerapkan nasihat yang ada dalam puisi lisan palebohu di kehidupan sehari-hari. Pertanyaan tersebut termasuk dalam aspek intelektual atau pengetahuan karena memerlukan wawasan dari masyarakat apakah masih menerapkan nasihat puisi lisan palebohu dalam kehidupan sehari-hari atau tidak. Hal itu terbukti dari $60 \%$ responden menjawab ya dan $40 \%$ menjawab tidak. Responden yang menjawab ya menanggapi:

Pertama, karena nasihat yang terdapat dalam puisi lisan palebohu mengandung pelajaran untuk berumah tangga yang berlandaskan pada nilai-nilai agama. Setiap keluarga yang ingin membuat rumah tangganya selalu bahagia mereka akan melaksanakan atau menerapkan isi nasehat puisi lisan palebohu.

Alasan kedua, bahwa dalam keluarga masih ada yang bertengkar dan berakhir dengan bercerai. Hal tersebut terjadi karena mereka tidak menerapkan nasihat yang ada dalam puisi lisan palebohu dan hanya mengikuti prinsipnya masing-masing yang mungkin saja membuat keluarganya hancur berantakan. Prinsip merupakan sebuah keyakinan yang dipegang teguh oleh pribadi orang masing-masing. Jika antara kedua pengantin memiliki prinsip masing-masing dan tidak bisa menyatukan kedua prinsip tersebut maka yang akan terjadi hanyalah sebuah pertengakaran yang akan berujung perceraian. Fungsi nasehat puisi lisan palebohu ini bisa mengatasi masalah-masalah yang ada dalam keluarga.

Berikut di bawah ini tabel untuk melihat eksistensi puisi lisan palebohu dari segi pelestarian puisi lisan palebohu.

Tabel 10. Pelestarian Puisi Lisan Palebohu

\begin{tabular}{|c|c|c|c|c|}
\hline \multirow{2}{*}{ Indikator } & \multicolumn{2}{|c|}{ Jawaban Respoden } & \multicolumn{2}{|c|}{ Presentase } \\
\hline & $\mathrm{Ya}$ & Tidak & Ya & Tidak \\
\hline $\begin{array}{l}\text { Menurut } \\
\text { Bapak/Ibu/Saudara apakah } \\
\text { puisi lisan palebohu ini } \\
\text { masih perlu untuk } \\
\text { dilestarikan? }\end{array}$ & 25 & 0 & $100 \%$ & 0 \\
\hline
\end{tabular}

Tabel di atas menunjukkan bahwa puisi lisan palebohu ini masih perlu untuk dilestarikan. Pertanyaan tersebut termasuk dalam aspek emosional karena membutuhkan kejujuran dari responden terhadap pelestarian puisi lisan palebohi kedepannya. Hal ini dapat dibuktikan dengan 100\% responden yang menjawab ya. Responden yang menjawab ya memiliki respons yang sama bahwa puisi lisan palebohu ini merupakan salah satu aset adat kebudayaan Gorontalo yang perlu untuk dilestarikan kepada generasi yang akan datang sehingga kebudayaan Gorontalo akan selalu hidup dan berkembang di setiap zaman.

Kebudayaan Gorontalo akan selalu hidup dan berkembang di setiap zaman, jika generasi yang datang mengerti bahwa isi yang ada dalam puisi lisan palebohu ini sangat bermanfaat bagi yang ingin membangun keluarga baru. Sehingga kebudayaan lain (barat) tidak mudah masuk dan menggantikan kebudayaan Gorontalo. Dengan masih adanya pelestarian yang dilaksanakan di desa Huntulohulawa Kecamatan Bongomeme diharapkan di desa-desa lain juga akan melakukan gerakan pelestarian terhadap puisi lisan palebohu tersebut. 
Berikut di bawah ini tabel untuk melihat eksistensi puisi lisan palebohu dari segi pelestarian puisi lisan palebohu.

Tabel 11. Pembatasan Usia

\begin{tabular}{lcccc}
\hline \multirow{2}{*}{ Indikator } & \multicolumn{2}{c}{ Jawaban Respoden } & \multicolumn{2}{c}{ Presentase } \\
\cline { 2 - 5 } & Ya & Tidak & Ya & Tidak \\
\hline $\begin{array}{l}\text { Apakah } \\
\text { Bapak/Ibu/Saudara setuju } \\
\text { ada batas usia untuk }\end{array}$ & 5 & & & \\
$\begin{array}{l}\text { mendengarkan puisi lisan } \\
\text { palebohu }\end{array}$ & & 20 & $20 \%$ & $80 \%$ \\
\hline
\end{tabular}

Tabel 11 menunjukkan bahwa $80 \%$ responden tidak setuju untuk adanya batas usia yang mendengarkan puisi lisan palebohu dan $20 \%$ lainnya setuju. Responden yang menjawab tidak setuju memiliki respons yang sama bahwa puisi lisan palebohu ini adalah warisan Gorontalo yang memiliki makna dan pelajaran yang sangat baik untuk semua kalangan masyarakat. Jadi, semuanya wajib mendengarkan baik dari kalangan anak-anak ataupun orang dewasa. Hal ini juga akan membuat generasi muda mengerti dengan isi yang ada dalam puisi lisan palebohu. Pertanyaan tersebut termasuk dalam aspek emosional karena memerlukan atau melihat bagaimana sikap masyarakat dalam menjawab pertanyaan tersebut. Berikut alasannya dapat dilihat di bawah ini.

Responden yang menanggapi bahwa mereka setuju dengan adanya batas usia untuk orang yang mendengarkan puisi lisan palebohu, maksud adalah anak-anak yang berusia 10 tahun ke bawah karena mereka masih anak-anak. Usia yang seharusnya bisa mendengarkan puisi lisan palebohu adalah anak yang berusia 12 tahun sampai ke atas karena mereka sudah mengerti nasehat yang ada dalam puisi lisan palebohu.

Berikut di bawah ini tabel untuk melihat eksistensi puisi lisan palebohu dari segi pelestarian puisi lisan palebohu.

Tabel 12. Palebohu Dijadikan Bahan Ajar

\begin{tabular}{lcccc}
\hline \multirow{2}{*}{ Indikator } & \multicolumn{2}{c}{ Jawaban Respoden } & \multicolumn{2}{c}{ Presentase } \\
\cline { 2 - 5 } & Ya & Tidak & Ya & Tidak \\
\hline $\begin{array}{l}\text { Apakah } \\
\begin{array}{l}\text { Bapak/Ibu/Saudara setuju } \\
\text { jika puisi lisan palebohu } \\
\text { dijadikan sebagai bahan } \\
\text { pelajaran di sekolah? }\end{array}\end{array}$ & 16 & 9 & & \\
\hline
\end{tabular}

Tabel 12 merupakan pertanyaan yang terkategori dalam aspek yaitu aspek emosional, karena memiliki dua gabungan antara sikap apakah setuju atau tidak jika puisi lisan palebohu dijadikan bahan ajar di sekolah. Hasil tersebut menunjukkan bahwa $64 \%$ responden menjawab ya dan $36 \%$ menjawab tidak. Responden yang menjawab ya memiliki respons yang sama yaitu dengan adanya pelajaran puisi lisan palebohu maka generasi yang akan datang mengerti dengan adat-adat Gorontalo. Puisi lisan palebohu akan lebih muda diterima oleh generasi yang akan datang.

Puisi lisan palebohu ini bagus untuk dibelajarkan di sekolah-sekolah terintegrasi dalam pelajaran mulok agar siswa bisa mengenal budaya Gorontalo lebih 
dalam dan dengan cara itu akan lahirlah pelestari atau penutur dari puisi lisan palebohu. Hal ini di dukung oleh hasil wawancara yang mengatakan jika puisi lisan palebohu ini dibelajarkan di sekolah-sekolah maka puisi lisan palebohu tidak akan mudah punah.

Responden yang menjawab tidak setuju dijadikannya puisi lisan palebohu sebagai bahan pelajaran di sekolah, karena budaya atau adat yang berisikan nasehat pernikahan dibelajarkan di sanggar seni dan budaya saja. Jika, dibelajarkan di sanggar akan lebih terarah dan siswa-siswanya akan lebih fokus. Jika, dibelajarkan di sekolah pikiran mereka pasti akan terbagi dengan pelajaran-pelajaran lainnya.

Berdasarkan indikator kebermaknaan puisi lisan palebohu, relevansi puisi palebohu dengan perkembangan zaman, manfaat puisi lisan palebohu untuk pengantin dan pendengar, dan pelestarian puisi lisan palebohu, yang tersebut dalam 12 pertanyaan memperoleh hasil presentase yaitu responden menjawab ya $7,23 \%$ dan yang menjawab tidak $2,76 \%$.

\section{PENUTUP}

Berdasarkan uraian pada pembahasan, dapat ditarik simpulan sebagai berikut. Pertama, secara fisik dalam penampilan, sastra lisan palebohu sudah jarang bahkan tidak ada lagi dalam upacara adat perkawinan masyarakat Gorontalo saat ini. Kedua, meskipun tidak dapat ditemukan lagi dalam upacara adat perkawinan, masyarakat masih menanggapi positif eksistensi sastra lisan palebohu karena dianggap masih bermakna, masih relevansi dengan perkembangan zaman sekarang, dianggap bermanfaat bagi untuk pendengar (khususnya pengantin), serta masih adanya adanya kesempatan untuk melestarikan puisi lisan palebohu.

\section{DAFTAR PUSTAKA}

Didipu, Herman. 2013. Sastra Daerah: Konsep Dasar dan Ancangan penelitiannya. Yogyakarta: Deepublish.

Hutomo, Suripan Sadi. 2001. Mutiara yang Terlupakan: Pengantar Studi Sastra Lisan. Surabaya: HISKI Jawa Timur.

Segers, Rien T. 2000. Evaluasi Teks Sastra: Sebuah Penelitian Eksperimental Berdasarkan Teori Semiotik dan Estetika Resepsi. Penerjemah Sumianto Sayuti. November: Mitra Gama Widya.

Tuloli, Nani. 1995. Khazanah Sastra Lisan. Gorontalo: STKIP Gorontalo. 